\title{
Identification of Heterotrimeric G Protein $\gamma 3$ Subunit in Rice Plasma Membrane
}

\author{
Aki Nishiyama ${ }^{\dagger}$, Sakura Matsuta ${ }^{\dagger}$, Genki Chaya, Takafumi Itoh, Kotaro Miura and \\ Yukimoto Iwasaki * \\ Department of Bioscience and Biotechnology, Fukui Prefectural University, 4-1-1 Kenjojima, Matsuoka, \\ Eiheiji-Town, Fukui 910-1195, Japan; s1873016@g.fpu.ac.jp (A.N.); s1873018@g.fpu.ac.jp (S.M.); \\ s1873012@g.fpu.ac.jp (G.C.); ito-t@fpu.ac.jp (T.I.); miura-k@fpu.ac.jp (K.M.) \\ * Correspondence: iwasaki@fpu.ac.jp; Tel.: +81-776-61-6000 (ext. 3514) \\ + These authors contributed equally to this work.
}

Received: 3 September 2018; Accepted: 7 November 2018; Published: 14 November 2018

\begin{abstract}
Heterotrimeric $G$ proteins are important molecules for regulating plant architecture and transmitting external signals to intracellular target proteins in higher plants and mammals. The rice genome contains one canonical $\alpha$ subunit gene (RGA1), four extra-large GTP-binding protein genes (XLGs), one canonical $\beta$ subunit gene (RGB1), and five $\gamma$ subunit genes (tentatively named RGG1, RGG2, RGG3/GS3/Mi/OsGGC1, RGG4/DEP1/DN1/OsGGC3, and RGG5/OsGGC2). RGG1 encodes the canonical $\gamma$ subunit; $R G G 2$ encodes the plant-specific type of $\gamma$ subunit with additional amino acid residues at the N-terminus; and the remaining three $\gamma$ subunit genes encode the atypical $\gamma$ subunits with cysteine abundance at the C-terminus. We aimed to identify the RGG3/GS3/Mi/OsGGC1 gene product, $\mathrm{G} \gamma 3$, in rice tissues using the anti-G $\gamma 3$ domain antibody. We also analyzed the truncated protein, $\mathrm{G} \gamma 3 \Delta \mathrm{Cys}$, in the RGG3/GS3/Mi/OsGGC1 mutant, $M i$, using the anti-G $\gamma 3$ domain antibody. Based on nano-liquid chromatography-tandem mass spectrometry (LC-MS/MS) analysis, the immunoprecipitated $G \gamma 3$ candidates were confirmed to be $G \gamma 3$. Similar to $\alpha(G \alpha)$ and $\beta$ subunits $(G \beta), G \gamma 3$ was enriched in the plasma membrane fraction, and accumulated in the flower tissues. As RGG3/GS3/Mi/OsGGC1 mutants show the characteristic phenotype in flowers and consequently in seeds, the tissues that accumulated $G \gamma 3$ corresponded to the abnormal tissues observed in RGG3/GS3/Mi/OsGGC1 mutants.
\end{abstract}

Keywords: GS3; $\gamma$ subunit; heterotrimeric G protein; mass spectrometric analysis; RGG3; rice; western blotting

\section{Introduction}

Heterotrimeric $G$ proteins are well known to consist of three subunits, $\alpha, \beta$, and $\gamma$, in mammals and yeast [1-4]. Receptors regulating the heterotrimeric $G$ proteins, such as $G$ protein-coupled receptors (GPCRs), interact with external signals and activate the heterotrimeric $G$ proteins via the intrinsic GDP/GTP exchange factor (GEF) of GPCRs. When GTP binds to the $\alpha$ subunit (G $\alpha$-GTP), heterotrimeric $G$ proteins dissociate into the $\alpha$ subunit $(\mathrm{G} \alpha-\mathrm{GTP})$ and $\beta \gamma$ dimer. The $\alpha$ subunit and $\beta \gamma$ dimer can regulate respective effector molecules. Thus, heterotrimeric $G$ proteins are signal mediators from receptors to effector molecules. In higher plants, heterotrimeric $G$ proteins are important molecules for regulating plant architecture and transmitting external signals to intracellular target proteins [5-7]. The biochemical characteristics of the plant heterotrimeric G protein [5] and the signaling mechanism and effector molecules regulating the plant heterotrimeric $G$ protein [6] have been previously reviewed. The plant morphology of heterotrimeric $G$ protein mutants has also been previously summarized [7]. There are three extra-large GTP-binding protein 
genes (AtXLG1 AtXLG3) [8,9], one canonical $\alpha$ subunit gene (GPA1) [10], one canonical $\beta$ subunit gene (AGB1) [11], and three $\gamma$ subunit genes (AGG1 AGG3) [12-14], in Arabidopsis; and four extra-large GTP-binding protein genes (prediction by in silico) [15], one canonical $\alpha$ subunit gene (RGA1) [16], one canonical $\beta$ subunit gene (RGB1) [17], and five $\gamma$ subunit genes, which we tentatively named RGG1 [18], RGG2 [18], RGG3/GS3/Mi/OsGGC1 [19], RGG4/DEP1/DN1/OsGGC3 [20], and RGG5/OsGGC2 [21], in this paper.

With regard to the $\gamma$ subunit genes in Arabidopsis, there are AGG1 and AGG2 encoding the canonical $\gamma$ subunits, and $A G G 3$ encoding the atypical $\gamma$ subunit with cysteine abundance at the C-terminus. In rice, RGG1 encodes the canonical $\gamma$ subunit, $R G G 2$ encodes the plant-specific type of $\gamma$ subunit, and the remaining three $\gamma$ subunit genes, RGG3/GS3/Mi/OsGGC1, RGG4/DEP1/DN1/OsGGC3, and RGG5/OsGGC2 encode the atypical $\gamma$ subunits homologous to AGG3. RGG3 corresponds to GRAIN SIZE 3 (GS3) [19] and RGG4 corresponds to DENSE AND ERECT PANICLES 1 (DEP1/DN1) [20]. The genome sequence of $R G G 5$ was predicted by Botella [21]. The diversity and agronomical importance of plant $\gamma$ subunits have been previously reviewed [21,22].

Mutants of XLG1, XLG2, and XLG3 [23]; GPA1 [24]; AGB1 [25,26]; and AGG1, AGG2 [27], and AGG3 [14] were isolated as heterotrimeric G protein mutants in Arabidopsis. Mutants of RGA1 [28,29], GS3 [30], and DEP1 [20] were isolated as similar G protein mutants in rice. By morphological analysis of gpa1 [24], agb1 [26], d1 [31], and RGB1 knock-down lines [32], it was shown that plant heterotrimeric $G$ proteins modulate cell proliferation.

It has been shown that plant heterotrimeric $G$ proteins are associated with transduction in response to multiple external signals, namely auxin [24,26], abscisic acid [33-37], gibberellin [38-41], brassinosteroid [24,39,40], sugar [42,43], blue light [44,45], and ozone [46]. It was also shown that the heterotrimeric $G$ proteins of plants are concerned with defense signaling [47-50].

Based on the characteristics of heterotrimeric $G$ proteins in higher plants, the $\alpha$ subunit is suggested to be contained in a huge complex localized in the plasma membrane fraction of rice [18] and Arabidopsis [51]. In rice, some $\beta \gamma$ dimer candidates seem to be present in two different forms: one is a component of a huge complex, and the other is a sole $\beta \gamma$ dimer dissociated from a huge complex in the plasma membrane of rice seedlings [18]. Using yeast two-hybrid screening, it was shown that 68 highly interconnected proteins form the core G-protein interactome in Arabidopsis [52], in which the regulators of G protein signaling protein (AtRGS1) [53], THYLAKOID FORMATION 1 (THF1) [43], cupin domain protein (AtPrin1) [35] etc. in addition to $\alpha, \beta, \gamma 1, \gamma 2$ subunits, were contained. The huge complexes prepared solubilized plasma membrane fraction in rice [18] and Arabidopsis [51] may represent a part of the G-protein interactome in Arabidopsis [52].

In mammals and yeast, $\beta$ subunits interact with $\gamma$ subunits to form the $\beta \gamma$ dimer [1-4]. The $\beta \gamma$ dimer has not been purified from the tissues of higher plants so far, but many studies suggest its presence based on the experiments, including an in vitro pull-down assay [12,13], yeast two-hybrid (Y2H) assay [13], split-ubiquitin system [14], and fluorescence response energy transfer (FRET) assay [51,54] in Arabidopsis. Moreover, in rice, the $\beta$ subunit was shown to interact with the $\gamma 1$ and $\gamma 2$ subunits with a $\mathrm{Y} 2 \mathrm{H}$ assay [18]. Recently, the interaction of rice $\beta$ subunit with atypical $\gamma$ subunits and the localization of these subunits in the plasma membrane were demonstrated with a bi-molecular fluorescence complementation $(\mathrm{BiFC})$ assay $[55,56]$. These results indicated that both the canonical and atypical $\gamma$ subunits can interact with the $\beta$ subunit, and that $\beta \gamma$ dimers are localized in the plasma membrane fraction, in Arabidopsis and rice.

GS3 is identified as a major QTL for grain weight and grain length, and as an important gene for agriculture [19,30,56-58]. According to the identification of AGG3 in Arabidopsis, GS3 was classified as the atypical $\gamma$ subunit member, and tentatively named RGG3. In order to understand the mechanism of seed formation in rice, studies on the GS3 protein are important.

To understand the function of RGG3 in the regulation of seed size, identifying the native $G \gamma 3$ protein is important. When the native $G \gamma 3$ protein is identified, biochemical analysis, namely measuring the subunit stoichiometry and affinity to $G \beta$, canonical $G \alpha$, and XLGs, is possible. Although 
we tried to identify the native $G \gamma 3$ protein using an anti-G $\gamma 3$ domain antibody, the antibody recognized multiple proteins. To identify the native $G \gamma 3$ protein, we use the RGG3 mutants MINUTE (Mi) and GS3-3, which produce partially defective proteins, as references for subtraction to Taichung 65 (abbreviated as WT [wild-type] hereinafter). Here, we find a candidate of the native RGG3 protein, $G \gamma 3$. Finally, we confirmed that the candidate was the native $G \gamma 3$ protein using nano-liquid chromatography-tandem mass spectrometry (LC-MS/MS) analysis of the immunoprecipitation products using an anti-G $\gamma 3$ domain antibody. Using this antibody, the subcellular localization and tissue-specific accumulation of the native $\mathrm{G} \gamma 3$ protein were studied.

\section{Result}

\subsection{Morphology of Rice Heterotrimeric G Protein $\gamma 3$ Gene (RGG3/GS3/Mi/OsGGC1) Mutants:}

To confirm the functions of rice heterotrimeric $G$ protein $\gamma 3$ subunit in determining the plant morphology, we prepared plants possessing GS3-3 [30] and Mi [58] mutation with Taichung 65 as a background. The mutant, Mi was slightly dwarfed (Figure 1A) and set small seeds (Figure 1B), compared to those of the WT. GS3-3 had a height similar to that of the WT (Figure 1A) and set large seeds (Figure 1B). These results indicate that the mutations in Mi and GS3-3 clearly affected the seed size.

(A)

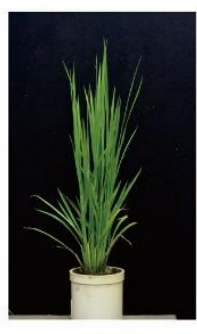

WT

(B)

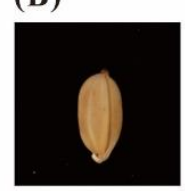

WT

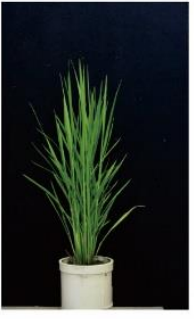

$M i$

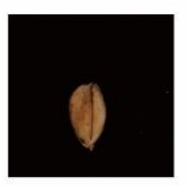

$M i$

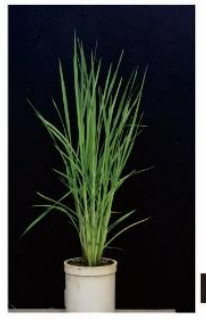

GS3-3

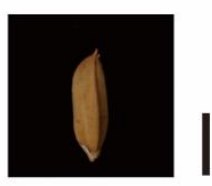

GS3-3
GS3-3:

C165A in cDNA: $\quad \Delta 13$ (Deletion of

( C)

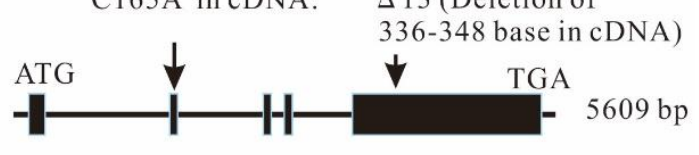

(D)

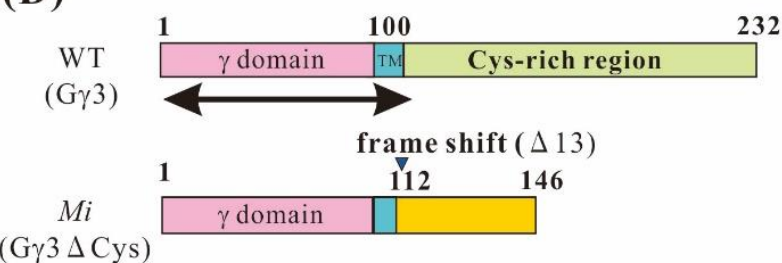

$\begin{array}{rlll} & \mathbf{1} & \mathbf{5} 5 & \text { nonsense mutation }(\mathbf{C 1 6 5 A}) \\ \text { GSS3-3 } & \Delta \gamma \text { domain } & \text { TG } \underline{C}(\mathrm{Cys}) \rightarrow \mathrm{TG} \underline{\mathrm{A}}(\text { Stop codon })\end{array}$

(G 33 s domain)

Figure 1. Morphology of rice heterotrimeric $G$ protein $\gamma 3$ gene (RGG3/GS3/Mi/OsGGC1) mutants, and genome and protein structure of RGG3/GS3/Mi/OsGGC1. (A) Gross morphology of the wild-type (WT) (Taichung 65), Mi and GS3-3; Bar $=10 \mathrm{~cm}$. (B) Seed morphologies of the plants in (A); Bar = $5 \mathrm{~mm}$. (C) Genome structure of RGG3/GS3/Mi/OsGGC1 and positions of mutations in RGG3/GS3/Mi/OsGGC1 mutants, Mi and GS3-3. The 13-base deletion (336-348th base in full-length cDNA) and one base substitution (C165A in full-length cDNA) had occurred in Mi and GS3-3, respectively. In GS3-3, a codon, TGC (cysteine) changed to TGA (stop codon). (D) Protein structure of the product of RGG3/GS3/Mi/OsGGC1 in the WT (G $\gamma 3), M i(G \gamma 3 \Delta$ Cys), and GS3-3 (G $\gamma 3 \Delta \gamma$ domain). The canonical $\gamma$ domain region is shown as $\gamma$ domain (pink bar). The putative transmembrane domain is indicated as TM (blue bar). The region with cysteine abundance is labeled as cysteine-rich region (green bar). The newly produced amino acid sequence by the frame shift resulting from of 13-base deletion is indicated with a yellow bar. An arrow under the WT G $\gamma 3$, which covers 120 amino acid residues from $\mathrm{N}$-terminal, is the region used for recombinant proteins, such as the thioredoxin (Trx)-tagged G 33 domain protein (Trx-G $\gamma 3$ domain protein), used as an antigen, and the glutathione $S$ transferase (GST)-tagged G $\gamma 3$ domain protein (GST-G $\gamma 3$ domain protein), used for affinity purification of the antibody. 


\subsection{Genomic Structure of $R G G 3$ and Protein Structure of $G \gamma 3$}

The genome sequence of RGG3 was found in RAP-DB (Os03g0407400). We reconfirmed the genome sequence of RGG3. RGG3 consists of five exons (Figure 1C) and its translation product, $G \gamma 3$, comprises 232 amino acid residues. In order to prepare recombinant proteins, cDNA for RGG3 was isolated. The molecular weight of $\mathrm{G} \gamma 3$ calculated from the cDNA, was $24249 \mathrm{Da}$. The $\mathrm{G} \gamma 3$ consists of the canonical $\gamma$ domain (about 100 amino acid residues), a short region with hydrophobic amino acid residues (tentatively named transmembrane region: TM), and a region with a large number of cysteines (Cys-rich region) (Figure 1D).

The Mi mutation occurred as a result of the deletion of 13 bases in RGG3. The mutation site corresponds to 336-348th positions in the full-length cDNA of RGG3, resulting in a frame-shift (Figure 1C). We reconfirmed the mutation in $\mathrm{Mi}$. In $\mathrm{Mi}$, the mutated protein, tentatively named G $\gamma 3 \Delta$ Cys, consists of 146 amino acid residues (Figure 1D). The cysteine-rich region is absent in G $\gamma 3 \Delta$ Cys. The molecular weight of $\mathrm{G} \gamma 3 \Delta$ Cys, calculated from cDNA, was 15,651 Da.

The GS3-3 mutation occurred as a result of one base substitution. The $C$ at the 165 th position in the full-length cDNA of RGG3 was substituted by A (C165A), resulting in the generation of a stop codon (Figure 1C). As the mutation in TCM3-467 was the same as that in GS3-3 [18], we renamed TCM3-467 to GS3-3. The GS3-3 mutation generated a mutated protein with 55 amino acid residues, tentatively named the $\mathrm{G} \gamma 3 \Delta \gamma$ domain (Figure 1D). The $\mathrm{G} \gamma 3 \Delta \gamma$ domain is an immature protein lacking about half of the canonical $\gamma$ domain. The molecular weight of the G $\gamma 3 \Delta \gamma$ domain, calculated from cDNA, was $5653 \mathrm{Da}$. The chemiluminescent intensity of G $\gamma 3 \Delta$ Cys was more than 7-fold that of $\mathrm{G} \gamma 3$, when $10 \mu \mathrm{g}$ of protein of the plasma membranes of the WT and Mi, respectively, was analyzed by western blot.

\subsection{G $\gamma 3$ Candidates Localized in the Plasma Membrane Fraction}

Identification of native $\mathrm{G} \gamma 3$ was carried out by Western blotting. As mutants have no native full length $G \gamma 3$, these were used as references, in order to identify native $G \gamma 3$ in WT. The plasma membrane fraction was chosen in this study as it was shown that $G \alpha$ and $G \beta$ accumulated in plasma membrane fraction in rice. The plasma membrane fractions of WT, GS3-3, and Mi flowers were prepared using an aqueous two-polymer phase system, and $\mathrm{G} \gamma 3$ candidates were detected by Western blotting using an anti-G $\gamma 3$ domain antibody. In the WT, a 32-kDa protein ( $\mathrm{G} \gamma 3$ candidate) was detected (Figure 2A, lanes 2 and 4); this band was not observed in GS3-3 or Mi. The molecular weight of the G $\gamma 3$ candidate is much higher than that of $\mathrm{G} \gamma 3$ calculated from the cDNA of the WT ( $24 \mathrm{kDa})$. In GS3-3, the G $\gamma 3 \Delta \gamma$ domain was not detected (Figure 2A, lane 3). In $M i$, a 20-kDa protein ( $\mathrm{\gamma} \gamma 3 \Delta \mathrm{Cys}$ candidate) was detected (Figure 2A, lane 5). The molecular weight of the $\mathrm{G} \gamma 3 \Delta \mathrm{Cys}$ candidate was much higher than that of $\mathrm{G} \gamma 3 \Delta$ Cys calculated from the cDNA (16 kDa). The molecular weights of $\mathrm{G} \gamma 3$ and $\mathrm{G} \gamma 3 \Delta \mathrm{Cys}$ candidates were measured using molecular weight markers (Figure 2B).

\subsection{Immunoprecipitation of $G \gamma 3$ and $G \gamma 3 \Delta C y$ s Using an Anti-G $\gamma 3$ Domain Antibody}

To concentrate $G \gamma 3$ and $G \gamma 3 \Delta$ Cys candidates, immunoprecipitation was carried out using anti-G $\gamma 3$ domain antibody. First, $50 \mu \mathrm{g}$ of the anti-G $\gamma 3$ domain antibody was added to $1 \mathrm{mg}$ each of solubilized plasma membrane protein of the WT (Figure 3A) and Mi (Figure 3B) flowers. G $\gamma 3$ and $\mathrm{G} \gamma 3 \Delta \mathrm{Cys}$ candidates were collected with the antibody cross-linked Protein A bound beads. The $32 \mathrm{kDa}$ protein, a G $\gamma 3$ candidate in the WT (Figure 3A, lane 3) and 20-kDa protein, a G $\gamma 3 \Delta$ Cys candidate in $M i$ (Figure 3B, lane 3), were immunoprecipitated. 
(A)

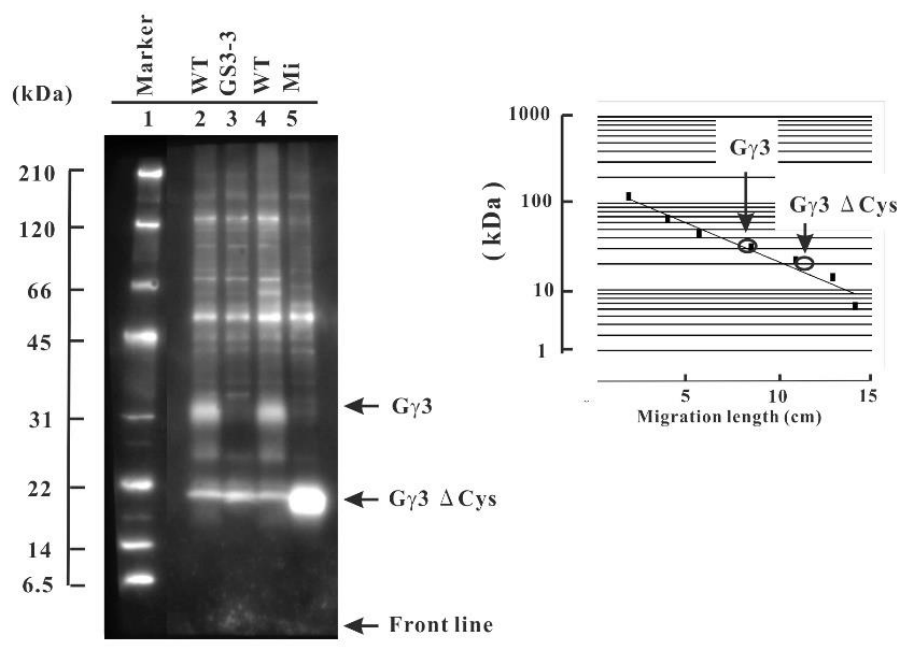

WB: anti-G $\gamma 3$ domain

Figure 2. Immunological study of the G $\gamma 3$ candidates in the wild-type (WT), Minute (Mi), and GS3-3 flowers. (A) First, $10 \mu \mathrm{g}$ of each protein of the plasma membrane fractions of the WT and GS3-3 and $5 \mu \mathrm{g}$ of the protein of the plasma membrane fractions of $M i$ were used for the Western blot analysis using an anti-G $\gamma 3$ domain antibody. Molecular weight marker (lane 1). The G $\gamma 3$ candidate was detected as a broad band with a molecular weight of approximately $32 \mathrm{kDa}$ in the WT (lanes 2 and 4). No G 33 was detected in GS3-3 (lane 3). The G $\gamma 3 \Delta$ Cys candidate was detected as a band with a molecular weight of approximately $20 \mathrm{kDa}$ in $\mathrm{Mi}$ (lane 5). (B) The molecular weights of $\mathrm{G} \gamma 3$ and $\mathrm{G} \gamma 3 \Delta \mathrm{Cys}$ candidates were estimated using a molecular weight marker as a standard.

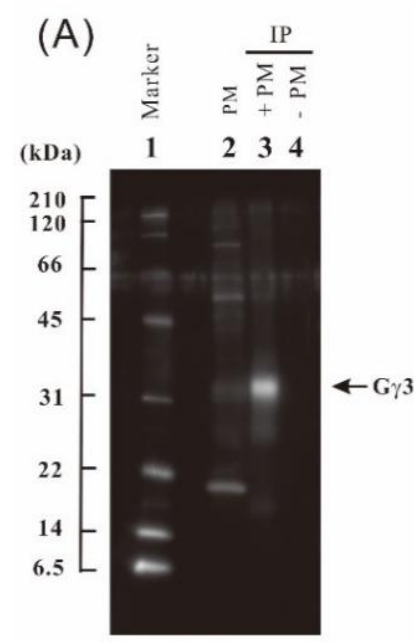

WB: anti-G $\gamma 3$ domain

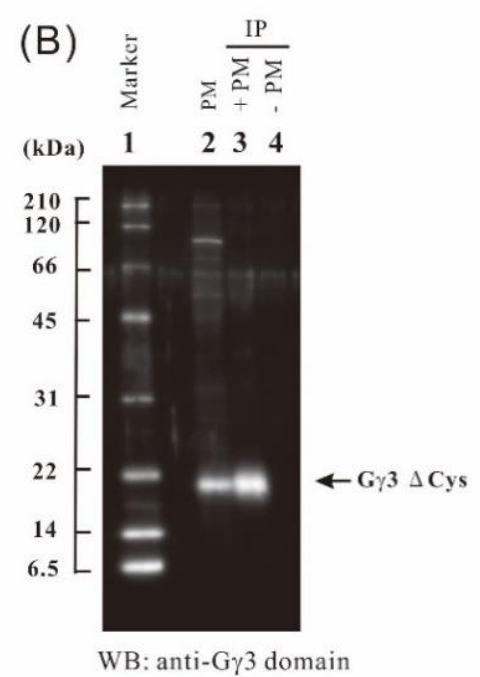

WB: anti-G $\gamma 3$ domain

Figure 3. Immunoprecipitation of $\mathrm{G} \gamma 3$ and $\mathrm{G} \gamma 3 \Delta$ Cys candidates. (A) Immunoprecipitation of the G $\gamma 3$ candidate from solubilized plasma membrane proteins of the wild-type (WT) flower using an anti-G $\gamma 3$ domain antibody. Molecular weight marker (lane 1); $10 \mu \mathrm{g}$ of protein of the plasma membrane fraction of the WT (lane 2); the immunoprecipitation product of solubilized plasma membrane proteins and anti-G $\gamma 3$ domain antibody (lane 3); control experiment (buffer in place of the membrane protein; lane 4). (B) Immunoprecipitation of the $G \gamma 3 \Delta$ Cys candidate from the solubilized plasma membrane proteins of the Minute (Mi) flower using an anti-G $\gamma 3$ domain antibody. Molecular weight marker (lane 1); $10 \mu \mathrm{g}$ of protein of the plasma membrane fraction of $M i$ (lane 2); the immunoprecipitation product of the solubilized plasma membrane proteins of $M i$ and the anti-G $\gamma 3$ domain antibody (lane 3); control experiment (buffer in place of the membrane protein; lane 4). 


\subsection{LC-MS/MS Analysis}

To demonstrate that $G \gamma 3$ and $G \gamma 3 \Delta$ Cys candidates are actually $G \gamma 3$ and $G \gamma 3 \Delta$ Cys, and that proteins with which the anti-G $\gamma 3$ domain antibody reacted, are actually $\mathrm{G} \gamma 3$ and $\mathrm{G} \gamma 3 \Delta \mathrm{Cys}$, LC-MS/MS analysis was carried out. First, using LC-MS/MS, we checked for G $\gamma 3$ and $G \gamma 3 \Delta C y s$ candidates in the eluate from the gel containing plasma membrane proteins following SDS-PAGE. When the signal intensities of $G \gamma 3$ and $G \gamma 3 \Delta$ Cys candidates detected by LC-MS/MS were not enough, we analyzed immunoprecipitation products, enriched with anti-G $\gamma 3$ domain antibody.

First, plasma membrane proteins from the WT and Mi were analyzed by LC-MS/MS. $40 \mu \mathrm{g}$ of each flower plasma membrane protein from WT and Mi was separated by SDS-PAGE and each lane was separated into 10 pieces to increase the relative amount of target proteins, according to the molecular weight marker. After these gel pieces were digested with trypsin, peptides were analyzed by LC-MS/MS in triplicate. Typical examples are summarized in Table 1. Fragments were assigned to the sequence of $G \gamma 3$, and their positions are indicated in Figure 4A.

In the analysis of the plasma membrane fraction of the WT, three $G \gamma 3$ fragments (fragments 1,2 , and 3) $(p<0.05)$ were detected in a gel piece containing a $32 \mathrm{kDa}$ protein (Table $1 \mathrm{~A})$. In the plasma membrane fraction of $M i$, three $\mathrm{G} \gamma 3$ fragments (fragments 2,3 , and $4-1)(p<0.05)$ were detected in a gel piece containing a $20 \mathrm{kDa}$ protein (Table 1B).

Table 1. LC-MS/MS analysis of G $\gamma 3$ fragments in in the plasma membrane of the wild-type (WT) and Minute $(\mathrm{Mi})$ flowers.

\begin{tabular}{cccccc}
\hline \multicolumn{6}{l}{ (A) G $\gamma 3$ fragments in the plasma membrane fraction of the WT flower } \\
\hline Fragments & Observed & Mr(expt) & Mr(calc) & Expected & Peptide \\
\hline 1 & 379.2251 & 1134.6536 & 1134.6509 & 0.00078 & R.LQLAVDALHR.E \\
2 & 714.7006 & 2141.08 & 2141.0753 & 0.00000034 & R.EIGFLEGEINSIEGIHAASR.C \\
3 & 482.7414 & 963.4682 & 963.4662 & 0.007 & R.EVDEFIGR.T \\
\hline
\end{tabular}

(B) G $\gamma 3$ fragments in the plasma membrane fraction of the Mi flower

\begin{tabular}{cccccl}
\hline Fragment & Observed & Mr(expt) & Mr(calc) & Expected & Peptide \\
\hline 2 & 714.7014 & 2141.0824 & 2141.0753 & 0.0000024 & R.EIGFLEGEINSIEGIHAASR.C \\
3 & 482.7408 & 963.4671 & 963.4662 & 0.0077 & R.EVDEFIGR.T \\
$4-1$ & 667.8468 & 1333.6791 & 1333.6765 & 0.00015 & R.TPDPFITISSEK.R \\
\hline
\end{tabular}

(C) $\mathrm{G} \gamma 3$ fragments in the immunoprecipitation products using the plasma membrane fraction of WT flower

\begin{tabular}{cccccl}
\hline Fragments & Observed & Mr(expt) & Mr(calc) & Expected & Peptide \\
\hline 1 & 568.3348 & 1134.6551 & 1134.6509 & $5.40 \times 10^{-7}$ & R.LQLAVDALHR.E \\
3 & 482.7417 & 963.4688 & 963.4662 & 0.00062 & R.EVDEFIGR.T \\
$4-2$ & 497.6015 & 1489.7827 & 1489.7776 & $2.50 \times 10^{-5}$ & R.TPDPFITISSEKR.S \\
\hline
\end{tabular}

(D) G $\gamma 3$ fragments in the immunoprecipitation products using the plasma membrane fraction of Mi flower

\begin{tabular}{cccccl}
\hline Fragments & Observed & Mr(expt) & Mr(calc) & Expected & Peptide \\
\hline 1 & 568.3354 & 1134.6562 & 1134.6509 & $8.90 \times 10^{-7}$ & R.LQLAVDALHR.E \\
2 & 714.7017 & 2141.0832 & 2141.0753 & $8.60 \times 10^{-7}$ & R.EIGFLEGEINSIEGIHAASR.C \\
3 & 482.7427 & 963.4709 & 963.4662 & 0.00072 & R.EVDEFIGR.T \\
$4-1$ & 667.8485 & 1333.6825 & 1333.6765 & $7.70 \times 10^{-6}$ & R.TPDPFITISSEK.R \\
\hline
\end{tabular}

Forty micrograms of each protein of the plasma membrane fraction of the wild-type (WT) and Minute (Mi) (A,B) and $5 \mu \mathrm{L}$ of each eluate in the immunoprecipitation experiment of WT and $M i(\mathbf{C}, \mathbf{D})$ were used for LC-MS/MS. Fragments of the trypsin-digested $\mathrm{G} \gamma 3$ candidates $(p<0.05)$ are shown. The fragment numbers correspond to Figure 4A. $\mathrm{Mr}(\mathrm{expt})$ and $\mathrm{Mr}$ (calc) correspond to the theoretical molecular mass and the molecular mass that was calculated from the observed molecular mass, respectively. The scores from the Mascot search were 91 (A), 90 (B), 164 (C), and 248 (D). 
(A) MAMAAAPRPKSPPAPPDPCGRHR ${ }_{1}$ LOLAVDALHR 2 EIGFLEGEINSI EGIHAASR CCR ${ }_{3}$ EVDEFIGR 4 TPDPFITISSEKR SHDHSHHFLKKFR CLCRASACCLSYLSWICCCSSAAGGCSSSSSSFNLKRPSCCCNCNCNC CSSSSSSCGAALTKSPCRCRRRSCCCRRCCCGGVGVRACASCSCSPPCA CCAPPCAGCSCRCTCPCPCPGGCSCACPACRCCCGVPRCCPPCL*

(B)

Fragment 1
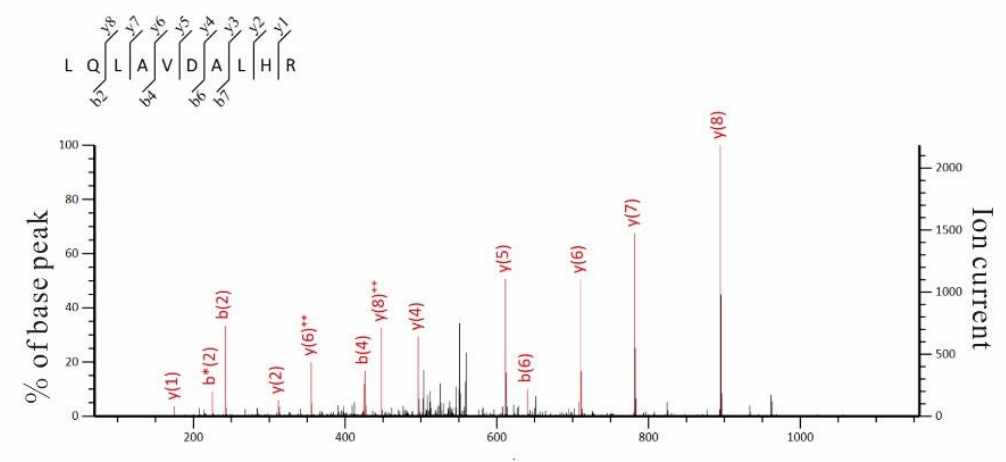

$\mathrm{m} / \mathrm{z}$

Fragment 3

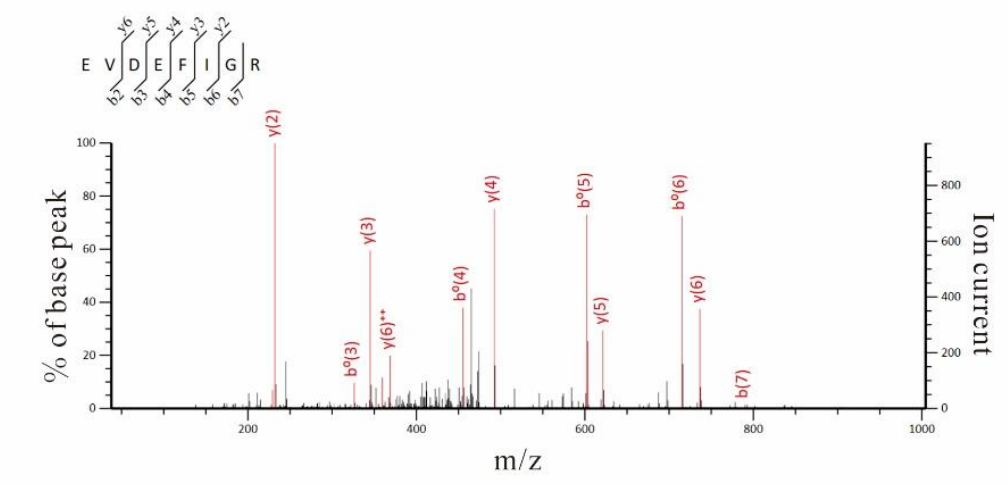

Fragment 4-2
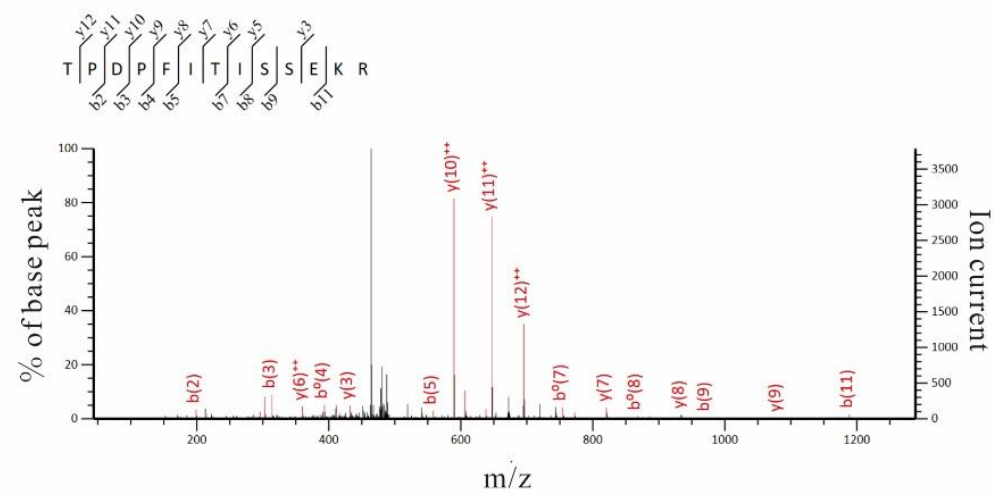

Figure 4. LC-MS/MS analysis of G $\gamma 3$ candidates. (A) Four peptides $(p<0.05)$, which were produced by trypsin-digested $G \gamma 3$ candidates in the wild-type (WT) and $M i$, were numbered and underlined in the full length $G \gamma 3$ amino acid sequence. These peptides are listed in Table 1. (B) MS/MS spectra of the three fragments, which were obtained from the immunoprecipitation product of $\mathrm{G} \gamma 3$ in the WT (Figure 3A, lane 3). Fragment numbers correspond to Table 1C.

Immunoprecipitation products were separated by SDS-PAGE and analyzed by LC-MS/MS. Immunoprecipitation products from the WT and Mi were not detected by silver staining (data not shown). In the immunoprecipitation products of the WT (Figure 3A, lane 3), a gel piece containing a $32 \mathrm{kDa}$ protein was cut and digested with trypsin, and the resultant peptides were analyzed by LC-MS/MS. As a result, three G $\gamma 3$ fragments (fragments 1, 3, and 4-2), represented as primary 
mass $(p<0.05)$, were obtained (Table 1C). Fragment 4-2 is an incomplete trypsin-digested fragment containing an arginine residue $(\mathrm{R})$ at its C-terminus, making it differ from fragment 4-1. In the immunoprecipitation products of $M i$, a gel piece containing a 20-kDa protein was cut and digested by trypsin, and the resultant peptides were analyzed by LC-MS/MS. As a result, four fragments (fragments 1, 2, 3, and 4-1) $(p<0.05)$ were obtained (Table 1D).

The MS/MS results of fragments 1,3, and 4-2 are shown in Figure 4B. Based on these results, we concluded that the $32 \mathrm{kDa}$ and $20 \mathrm{kDa}$ polypeptides were $\mathrm{G} \gamma 3$ and $\mathrm{G} \gamma 3 \Delta \mathrm{Cys}$, respectively. When the immunoprecipitation product of the WT was analyzed by LC-MS/MS, five fragments, SPCRCR, SCCCRR, RCCCGGVGVR, ACASCSCSPPCACCAPPCAGCSCR, and CCPPCL, which were positioned at the C-terminal parts of $G \gamma 3$, were detected by the Mascot search, but their scores were very low (Mascot score <11). Therefore, these five fragments were excluded from Table 1 and Figure 4A.

When the NCBI protein database was used for the analysis of $G \gamma 3$ candidates, $G \gamma 3$ was annotated using another name, BAH89202.1

\section{6. $G \gamma 3$ and $G \gamma 3 \Delta C y s$ Were Enriched in the Plasma Membrane Fraction}

To check whether $G \gamma 3$ and $G \gamma 3 \Delta$ Cys are enriched in the plasma membrane, the amount of $G \gamma 3$ and $G \gamma 3 \Delta$ Cys in the crude microsomal fraction was compared with that in the plasma membrane fraction (Figure 5). Tissue-homogenate was centrifuged at $10,000 \times g$ for $10 \mathrm{~min}$ and the resulting supernatant was centrifuged at $100,000 \times g$ for $1 \mathrm{~h}$. The precipitate $(100,000 \mathrm{~g} \mathrm{ppt})$ was named the crude microsomal fraction (cMS). The plasma membrane fractions were prepared from cMS, using the aqueous two-polymer phase system.

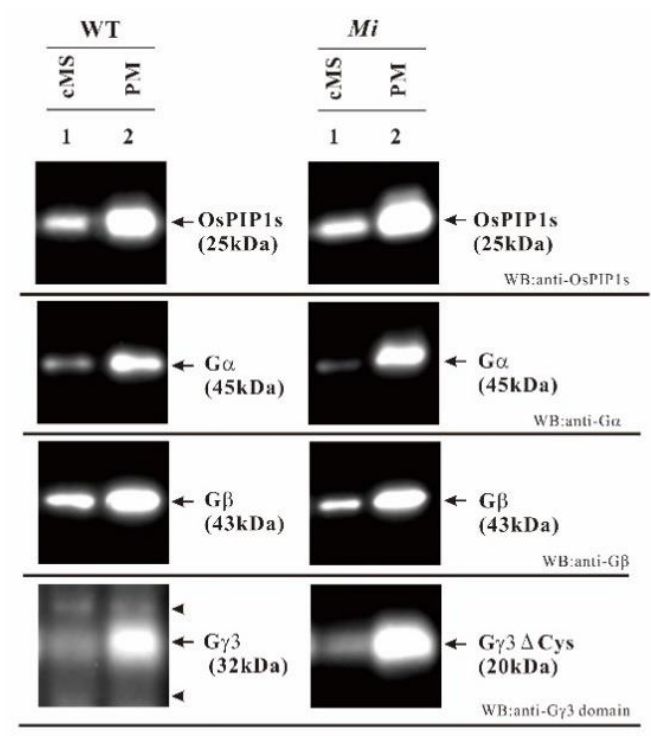

Figure 5. $G \gamma 3$ and $G \gamma 3 \Delta C$ ys were enriched in the plasma membrane fraction of the wild-type (WT) and Minute $(\mathrm{Mi})$ flowers. First $10 \mu \mathrm{g}$ of both the crude microsomal fraction protein and plasma membrane fraction protein from the WT and Mi were analyzed by western blot using anti-OsPIP1s, anti-G $\alpha$, anti-G $\beta$, and anti-G $\gamma 3$ domain antibodies. OsPIP1s is an aquaporin, which is a plasma membrane marker. OsPIP1s (25 kDa), G $\alpha$ (45 kDa), G $\beta$ (4 3kDa), G $\gamma 3(32 \mathrm{kDa})$, and G $\gamma 3 \Delta \mathrm{Cys}(20 \mathrm{kDa})$ are indicated by arrows. Non-specific bands are indicated by arrow heads.

OsPIP1s is an aquaporin, which is a plasma membrane marker. $G \alpha$ and $G \beta$ are the subunits of the heterotrimeric $G$ protein complex in rice. The OsPIP1s, $G \alpha$ subunit, and $G \beta$ subunit were enriched in the plasma membrane fraction. Furthermore, G $\gamma 3(32 \mathrm{kDa}$ in WT) and G $\gamma 3 \Delta \mathrm{Cys}(20 \mathrm{kDa}$ in $M i)$ were also enriched in the plasma membrane fraction. These results showed that G $\gamma 3$ (32 kDa in WT) and $\mathrm{G} \gamma 3 \Delta \mathrm{Cys}$ (20 kDa in $\mathrm{Mi}$ ) were localized in the plasma membrane fraction. 


\subsection{Tissue-Specific Accumulation of $\mathrm{G} \gamma 3$}

In order to know the tissues in which $G \gamma 3$ accumulates, the accumulation profile of $G \gamma 3$ was studied using the plasma membrane fractions of one-week-old etiolated seedlings of WT, developing leaf sheaths, and flowers. The results showed that the $G \gamma 3$ protein largely accumulated in the developing flower (Figure 6).

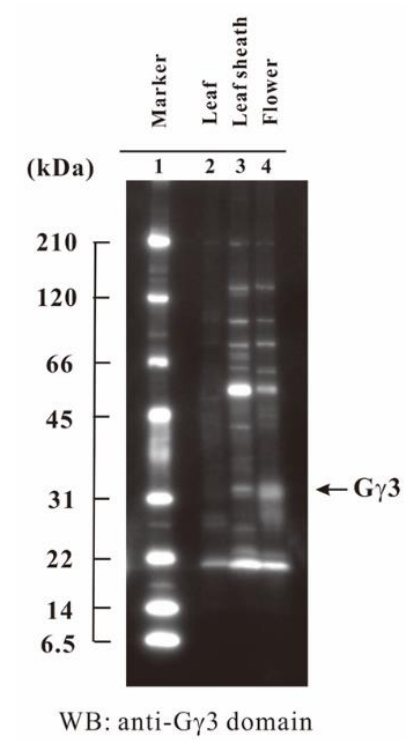

Figure 6. Tissue-specific accumulation of G $\gamma 3$ in the wild-type (WT). Ten micrograms of each of the plasma membrane fraction proteins of the leaf, leaf sheath, and flower in the WT was analyzed by SDS-PAGE and Western blotting using an anti-G $\gamma 3$ domain antibody. Molecular weight marker (lane 1); leaf from etiolated seedling (lane 2); developing leaf sheath at the eighth leaf stage (lane 3); $1-5 \mathrm{~cm}$ flower (lane 4).

\section{Discussion}

In rice, there are three atypical $\gamma$ subunit genes (RGG3, RGG4, and RGG5) that are homologous to AGG3. The tentatively named RGG3 corresponds to GRAIN SIZE 3 (GS3), which is a gene that regulates seed length [19,30,56-58] and RGG4 corresponds to DENSE AND ERECT PANICLE1 (DEP1), which is a gene that regulates plant architecture including semi-dwarfness, panicle number and panicle erectness [20,55]. RGG5 corresponds to GGC2 [21], which a gene that increases grain length in combination or individually with DEP1 [56]. These genes are important for rice breeding. These have been already cloned, but their native translation products have not yet been studied. In this study, we focused on the native translation products of $R G G 3 / G S 3 / M i / O s G G C 1$.

First, we detected the $G \gamma 3$ candidate from the WT and the truncated $G \gamma 3$ candidate (G $\gamma 3 \Delta$ Cys) from $M i$ by Western blotting using anti-G $\gamma 3$ domain antibodies (Figure 2A). In SDS-PAGE, the molecular weights of the $G \gamma 3$ and $G \gamma 3 \Delta$ Cys candidates were estimated as 32 and $20 \mathrm{kDa}$, respectively, which were larger than the molecular mass calculated using cDNAs, i.e., 24 and $16 \mathrm{kDa}$, respectively. These results indicate that modifications, such as glycosylation, ubiquitination, phosphorylation, and lipid modification (palmitoylation etc.), may have occurred after translation in the $\mathrm{G} \gamma 3$ and $\mathrm{G} \gamma 3 \Delta \mathrm{Cys}$ candidates. The identification of the modification is a subject requiring further study. In order to obtain concrete evidence on whether the $G \gamma 3$ and $G \gamma 3 \Delta$ Cys candidates detected by western blotting were actually $G \gamma 3$ and $G \gamma 3 \Delta$ Cys proteins, the immunoprecipitation products of the $\mathrm{G} \gamma 3$ and $\mathrm{G} \gamma 3 \Delta \mathrm{Cys}$ candidates were analyzed by LC-MS/MS (Figures 3 and 4). As a result, four fragments, with $p<0.05$ by the Mascot search engine, were obtained from the $G \gamma 3$ and $G \gamma 3 \Delta C y s$ candidates. These results indicated that the $G \gamma 3$ and $G \gamma 3 \Delta$ Cys candidates were actually $G \gamma 3$ and G $\gamma 3 \Delta$ Cys, respectively. 
Mutants of RGG3, i.e., $M i$ [58] and GS3-3 [30], set small and large seeds, respectively (Figure 1B). Thus, $R G G 3$ regulates seed morphology. $G \gamma 3$ and $G \gamma 3 \Delta$ Cys were accumulated in the plasma membrane fraction of the flower tissue (Figure 5). The tissue in which $G \gamma 3$ and $G \gamma 3 \Delta C y$ s were accumulated corresponded to the tissue that showed the morphological abnormalities in Mi and GS3-3 (Figures 1 and 6). One of the deletion alleles of GS3 decreased the cell number in the lemma and palea and a knock-down construct of GS3 utilizing RNAi increased the cell number [58]. G $\gamma 3$ also modulates cell proliferation, similar to $G \alpha$ [31] and $G \beta$ [32]. The chemiluminescent intensity of $G \gamma 3 \Delta$ Cys was more than 7-fold that of $G \gamma 3$ (Figure 2). The reason that the amount of $G \gamma 3$ was fewer than that of $G \gamma 3 \Delta$ Cys may be that $G \gamma 3$ is degraded by proteases. Another possibility could be that $G \gamma 3 \Delta$ Cys may stably accumulate in the plasma membrane with other proteins, including $G \beta$. Hence, further analysis of native and truncated $G \gamma 3$ s will be important to understanding seed size regulation.

Sun et al. reported that GS3-1 (corresponding to G $\gamma 3$ ) interacted with G $\beta$ using a Y2H assay [56]. Using BiFC, they also revealed that GS3-1 and GS3-4, truncated G $\gamma 3$ proteins in GS3-4, interacted with G $\beta$ on the plasma membrane [56]. GS3-4 in GS3-4 [30,56] and G $\gamma 3 \Delta$ Cys in Mi [58] consisted of 149 and 146 amino acid residues, respectively. GS3-4 and G $\gamma 3 \Delta$ Cys have the canonical G $\gamma$ domain and a putative transmembrane domain, but largely lack a cysteine-rich domain. In this study, native $G \gamma 3$ and G $\gamma 3 \Delta$ Cys were enriched in the rice plasma membrane, similar to the $G \beta$ subunit (Figure 5). We also confirmed that $G \gamma 3$ and $G \gamma 3 \Delta$ Cys interacted with $G \beta$ using a $Y 2 H$ assay (data not shown). From these results, it is suggested that $G \gamma 3$ and $G \gamma 3 \Delta$ Cys may form a dimer with $G \beta$ on the plasma membrane. As we identified $G \gamma 3$ and $G \gamma 3 \Delta$ Cys by immunological techniques and LC-MS/MS analysis in this study, it will be possible to research whether the $G \gamma 3$ protein is a component of the heterotrimeric $G$ protein complex containing the canonical G $\alpha$ and XLGs.

As the seeds of $M i[58]$ and GS3-4 [30,56] were shorter than those of the WT, G $\gamma 3 \Delta$ Cys is the cause of shortened seeds. It will be important to clarify whether $G \gamma 3 \Delta$ Cys interacts with $G \beta$. If the $\beta \gamma$ dimer composed with $\mathrm{G} \gamma 3 \Delta$ Cys is present in the plasma membrane, it will be interesting to research the interaction between the unusual $\beta \gamma$ dimer (G $\beta G \gamma 3 \Delta C y s)$ and the canonical $G \alpha$ or XLGs, on the basis of the $G$ protein signaling model $[5,6]$. As previously reported, some $\beta \gamma$ dimers seem to be present in two different fractions in gel filtration: one is a component of a huge complex, and the other is a sole $\beta \gamma$ dimer in the plasma membrane of etiolated rice seedlings [18]. Although this may be the result of artificial dissociation during solubilization and gel fractionation, this approach will be important for understanding the heterotrimeric G protein complex. Truncated G $\gamma 3$ in GS3-3, namely the $G \gamma 3 \Delta \gamma$ domain, consisted of 55 amino acid residues, which is considered as a loss of function of OSR (organ size regulation) [30]. In GS3-3, the G $\gamma 3 \Delta \gamma$ domain was not detected in the plasma membrane (Figure 2A). The reason may be due to the lack of the trans-membrane domain in the $G \gamma 3 \Delta \gamma$ domain or due to the lack of sites that anti-G $\gamma 3$ domain antibody recognizes in the $\mathrm{G} \gamma 3 \Delta \gamma$ domain. In addition, the $\mathrm{G} \gamma 3 \Delta \gamma$ domain was not detected in the cytosolic fraction (data not shown). However, it is not ruled out that there is no G $\gamma 3 \Delta \gamma$ domain in the cytosolic fraction, due to the detection threshold in Western blot not being met. As seeds of GS3-3 were longer than those of the WT, the lack of a $\beta \gamma 3$ dimer may be the cause of enlarged seeds. Hence, as we detected $G \gamma 3$ and $\mathrm{G} \gamma 3 \Delta \mathrm{Cys}$ proteins in this study, biochemical analysis of the heterotrimeric $\mathrm{G}$ protein complex in $\mathrm{Mi}$ and GS3-3 will be accelerated. It is of interest to reveal the subunit stoichiometry of the canonical $G \alpha$, XLGs, G $\beta$, and five $G \gamma$ s, namely $\gamma 1, \gamma 2$, the $G \gamma 3 \Delta \gamma$ domain, $\gamma 4$, and $\gamma 5$, and the subsequent subunit composition of the $\mathrm{G}$ protein complex in $M i$, which sets small grains. It is also important to analyze the subunit stoichiometry of the canonical G $\alpha$, XLGs, G $\beta$, and four G $\gamma$ s, namely $\gamma 1, \gamma 2, \gamma 4$, and $\gamma 5$, and the subsequent subunit composition of the G protein complex in GS3-3, which sets large grains. 


\section{Materials and Methods}

\subsection{Plant Materials}

A rice cultivar (Oryza sativa L. cv. Taichung 65) and two heterotrimeric G protein $\gamma 3$ mutants (GS3-3 and $\mathrm{Mi}$ ) were used in this study. GS3-3 was obtained from the Taichung 65 mutant library, mutagenized by N-methyl-N-nitrosourea treatment, and named TCM-3-467. The Mi mutation was provided from the stocked mutant line, H343 (Oryza sativa L. cv. Akamuro background). H343 was backcrossed four times with Taichung 65, and was used as a near-isogenic line of $M i$ in this study. All rice plants were grown under a 14-h light $\left(50,000\right.$ lux and $\left.28^{\circ} \mathrm{C}\right)$ and 10 -h dark $\left(25^{\circ} \mathrm{C}\right)$ cycle, or under natural field conditions.

\subsection{Sequencing and Confirmation of RGG3}

Genomic DNA was isolated from whole plants of WT, Mi, and GS3-3 using an extraction method with cetyltrimethylammonium bromide (CTAB) [59]. Using this as a template, PCR was performed using > 20 sets of PCR primers to cover 5609 bases of RGG3 (Os03g0407400). The amplified DNA fragments were directly sequenced using the same primers that were used for amplification.

\subsection{RNA Isolation, Reverse Transcription, and cDNA Encoding of the Heterotrimeric G Protein Gr3 Subunit}

Total RNA from the flower tissue was directly extracted using RNeasy Plant Mini kits (Qiagen, Hilden, Germany). The first strand of cDNA was synthesized using Super Script First Strand Synthesis System for RT-PCR (Invitrogen, Carlsbad, CA, USA). Total RNA (0.5 $\mu \mathrm{g})$ and oligo-dT were used as the template and primer, respectively, for the first strand cDNA synthesis.

In order to isolate RGG3 cDNA, the primers were designed based on the database information (Os03g0407400):

RGG3 forward: 5' atggcaatggcggcggcgcc 3';

RGG3 reverse: 5' caagcagggggggcagcaac 3'.

The amplified PCR products were sub-cloned into pCR4 (Invitrogen) and sequenced with a Thermo BigDye Terminator Cycle Sequencing Kit (Amersham Biosciences, Little Chalfont, UK) using a DNA sequencer (Model 377; Applied Biosystems, Foster City, CA, USA).

\subsection{Preparation of the Microsomal and Plasma Membrane Fractions in Rice}

Crude microsomal fractions were prepared from 2-5 cm flowers of the WT, Mi, and GS3-3, as described previously [18], and plasma membrane fractions were purified from the crude microsomal fraction using an aqueous two-polymer phase system [60]. From the etiolated seedlings, which were grown for $5 \mathrm{~d}$ at $28^{\circ} \mathrm{C}$, and developing leaf sheaths at the eighth leaf stage, crude microsomal fractions and plasma membrane fractions were prepared, respectively.

\subsection{SDS-Polyacrylamide Gel Electrophoresis (SDS-PAGE)}

Electrophoresis was carried out on $12.5 \%$ and $10 / 20 \%$ gradient polyacrylamide gels containing $0.1 \%$ SDS, as described previously [61].

For LC-MS/MS analysis, $40 \mu \mathrm{g}$ of flower plasma membrane proteins from both the WT and $M i$ were analyzed using 15\% SDS-PAGE. Electrophoresis was stopped at a position where the Bromophenol Blue was $3 \mathrm{~cm}$ away from the stacking gel. The $3-\mathrm{cm}$ long gel was divided into 10 pieces according to the molecular weight marker (Precision Plus Protein ${ }^{\mathrm{TM}}$ Kaleidoscope $^{\mathrm{TM}}$; Bio-Rad Laboratories), without staining. These gel pieces were used for trypsin digestion. In some cases, gels were silver-stained using Pierce Silver Stain for Mass Spectrometry (Thermo Scientific). 


\subsection{Preparation of Trx-G $\gamma 3$ and GST-G $\gamma 3$ Domain Proteins}

cDNA encoding 120 amino acid residues from the $\mathrm{N}$-terminal of the rice $\mathrm{G} \gamma 3$ protein was amplified by PCR using primers. The cDNA contains the $\mathrm{G} \gamma 3$ domain and the putative transmembrane region:

RGG3 domain forward: 5'ccttggctcatatggatatcatggcaatggeggcggcgccceggcccaag3';

RGG3 domain reverse: 5'aagcttccegggtcaggaggaggatgagcagccgccggcggcgctgctg3'.

Amplified cDNA was sub-cloned in pET32a containing thioredoxin (Trx) and histidine (His) tags (Novagen). The resultant clone, the Trx-G $\gamma 3$ domain vector, was transformed in T7 Express lys $Y / I^{q}$ E. coli (New England Biolabs), and the recombinant protein was synthesized and designated as the Trx-G $\gamma 3$ domain protein. The cDNA covering the $G \gamma 3$ domain was also sub-cloned in pET41 containing glutathione S-transferase (GST) and His tags (Novagen). The resultant clone, the GST-G $\gamma 3$ domain vector, was transformed in T7 Express lys $Y / I^{q}$ E. coli (New England Biolabs), and the recombinant protein was synthesized and designated as the GST-G $\gamma 3$ domain protein.

The overexpression of the Trx-G $\gamma 3$ domain protein and GST-G $\gamma 3$ domain protein in T7 Express lys $Y / I^{9}$ E. coli was carried out as described elsewhere [61]. Inductions were performed at $37^{\circ} \mathrm{C}$. Induction was initiated by the addition of IPTG (final IPTG concentration, $1 \mathrm{mM}$ ). After $3 \mathrm{~h}$, E. coli was harvested after centrifugation at $10,000 \times g$ for $5 \mathrm{~min}$ at $4{ }^{\circ} \mathrm{C}$, and stocked at $-80^{\circ} \mathrm{C}$ before use.

As the Trx-G $\gamma 3$ domain protein and GST-G $\gamma 3$ domain protein were included in the body, both proteins were solubilized in $6 \mathrm{M}$ guanidine hydrochloride, $10 \mathrm{mM}$ Tris $\mathrm{HCl}, \mathrm{pH}$ 8.0. Solubilized proteins were applied to Ni-NTA agarose (Qiagen, Hilden, Germany). The purification of both proteins was performed according to the protocols recommended by the manufacturers.

The antibody was raised against the Trx-G $\gamma 3$ domain protein in rabbits. Affinity purification of the antibody was performed using a polyvinylidene fluoride (PVDF) filter (Millipore, Burlington, MA, USA), immobilized with the GST-G $\gamma 3$ domain protein.

\subsection{Western Blot Analysis (WB)}

Proteins were separated by $12.5 \%$ or $10 / 20 \%$ gradient SDS-PAGE, and blotted onto a PVDF membrane (Millipore). The antibody against the rice $\mathrm{G} \gamma 3$ domain was affinity-purified in this study. Antibodies against the rice heterotrimeric $G$ protein $\alpha$ and $\beta$ subunits, namely the anti-G $\alpha$ and anti-G $\beta$ antibodies, were used as described previously [18]. The antibody against aquaporin (a plasma membrane marker), namely, anti-OsPIP1s, was purchased from Operon Biotechnologies. The Chemi-Lumi One Markers Kit (Nacalai Tesque, Kyoto, Japan) was used as a molecular weight marker for western blotting.

$\mathrm{ECL}^{\mathrm{TM}}$ peroxidase labelled anti-rabbit antibody was purchased as second antibody from GE Healthcare, Little Chalfont, UK. ECL Immobilon ${ }^{\mathrm{TM}}$ Western Chemiluminescent HRP Substrate (Millipore, Burlington, MA, USA) was used as the western blotting detection reagent. The chemiluminescent signal was measured using a Fusion SL (MS instruments).

\subsection{Immunoprecipitation}

First, $50 \mu \mathrm{g}$ of affinity-purified anti-G $\gamma 3$ domain antibody was bound to $50 \mathrm{mg}$ of Protein A bound magnetic beads (Millipore, Burlington, MA, USA). After washing them thrice with $1 \times$ PBS, the anti-G $\gamma 3$ domain antibody and Protein A were cross-linked with dimethyl pimelimidate dihydrochloride (DMP). The conditions followed for cross-linking were according to the protocols recommended by the manufacturers. After quenching the magnetic cross-linked beads with the anti-G $\gamma 3$ domain antibody, they were stored at $4{ }^{\circ} \mathrm{C}$ until use.

Next, $0.1 \mathrm{~mL}$ of $10 \%$ SDS was added to $0.9 \mathrm{~mL}$ of plasma membrane fraction (1 mg protein $/ 10 \mathrm{mg}$ $\mathrm{SDS} / \mathrm{mL}$ ) and denatured for $5 \mathrm{~min}$ at $90^{\circ} \mathrm{C}$. After diluting the solubilized fraction with $10 \mathrm{~mL}$ of $1 \times$ TBS containing $1 \%$ Tween 20 , the magnetic beads cross-linked with $50 \mu \mathrm{g}$ of the anti-G $\gamma 3$ domain antibody were added. After incubation for $2 \mathrm{~h}$ at $25^{\circ} \mathrm{C}$, the magnetic beads were collected into a $1.5 \mathrm{~mL}$ tube and washed thrice each with $0.5 \mathrm{~mL}$ of $1 \times$ TBS containing $0.1 \%$ Tween 20 and $0.5 \mathrm{~mL}$ of 
$1 \times$ TBS. Proteins were eluted using $40 \mu \mathrm{L}$ of dissociation buffer (Bio-rad) without a reducing agent, from the beads. In total, $5 \mu \mathrm{L}$ of each eluate was used for LC-MS/MS.

\subsection{Protein Reduction, Alkylation, and Trypsin Digestion for LC-MS/MS Analysis}

Gel pieces were resuspended in $50 \mathrm{mM} \mathrm{NH}_{4} \mathrm{HCO}_{3}$, reduced with $50 \mathrm{mM}$ dithiothreitol for $30 \mathrm{~min}$ at $56^{\circ} \mathrm{C}$, and alkylated with $50 \mathrm{mM}$ iodoacetamide for $30 \mathrm{~min}$ at $37{ }^{\circ} \mathrm{C}$ in the dark. Alkylated proteins in the gels were digested with $10 \mu \mathrm{g} / \mathrm{mL}$ of trypsin solution (Promega, Madison, WI, USA) for $16 \mathrm{~h}$ at $37^{\circ} \mathrm{C}$. The resultant peptides were concentrated and suspended in $0.1 \%$ formic acid and analyzed by LC-MS/MS.

\subsection{Protein Identification Using Nano-LC-MS/MS}

The peptides were loaded onto the LC system (EASY-nLC 1000; Thermo Fisher Scientific, Waltham, MA, USA) equipped with a trap column (EASY-Column, C18-A1 $5 \mu \mathrm{m}, 100 \mu \mathrm{m}$ ID $\times 20 \mathrm{~mm}$; Thermo Fisher Scientific), equilibrated with $0.1 \%$ formic acid, and eluted with a linear acetonitrile gradient $(0-50 \%)$ in $0.1 \%$ formic acid at a flow rate of $200 \mathrm{~nL} / \mathrm{min}$. The eluted peptides were loaded and separated on the column (C18 capillary tip column, $75 \mu \mathrm{m}$ ID $\times 120 \mathrm{~mm}$; Nikkyo Technos, Tokyo, Japan) with a spray voltage of $1.5 \mathrm{kV}$. The peptide ions were detected using MS (LTQ Orbitrap Elite MS; Thermo Fisher Scientific) in the data-dependent acquisition mode with Xcalibur software (version 2.2; Thermo Fisher Scientific). Full-scan mass spectra were acquired in MS over 400-1500 m/z with a resolution of 60,000 . The 10 most intense precursor ions were selected for collision-induced fragmentation in the linear ion trap, at a normalized collision energy of 35\%. Dynamic exclusion was employed within $90 \mathrm{~s}$ to prevent the repetitive selection of peptides.

\subsection{MS Data Analysis}

Protein identification was performed using the Mascot search engine (version 2.5.1, Matrix Science, London, UK) and the in-house database, which constructed the amino acid sequences of rice heterotrimeric $G$ protein subunits. For both the searches, the carbamidomethylation of cysteine was set as a fixed modification, and oxidation of methionine was set as a variable modification. Trypsin was specified as the proteolytic enzyme and one missed cleavage was allowed. The peptide mass tolerance was set at $10 \mathrm{ppm}$, fragment mass tolerance was set at $0.8 \mathrm{Da}$, and peptide charges were set at $+2,+3$, and +4 . An automatic decoy database search was performed as part of the search. Mascot results were filtered with the Percolator function to improve the accuracy and sensitivity of peptide identification. The minimum requirement for the identification of a protein was two matched peptides. Significant changes in the abundance of proteins between samples were determined $(p<0.05)$.

\subsection{Gene ID}

The accession numbers of the rice heterotrimeric $G$ proteins $\alpha, \beta$, and $\gamma 3$ subunit genes (RGA1, $R G B 1$, and $R G G 3$, respectively) are Os05g0333200, Os03g0669200, and Os03g0407400, respectively.

\section{Conflicts of Interests}

The authors declare no conflicts of interest.

Author Contributions: Investigation and formal analysis, A.N. and S.M.; methodology, T.I.; resources, G.C. and K.M.; writing and funding acquisition, Y.I.

Funding: This work was supported by a grant for Scientific Research from Fukui Prefectural University and the JSPS KAKENHI, Grant Number 26712001.

Acknowledgments: We thank Yasuo Nagato for providing TCM3-467 and Iturou Takamure for H343. Part of the work was performed at the Biological Resource Research and Development Center, Fukui Prefectural University (Fukui, Japan). 


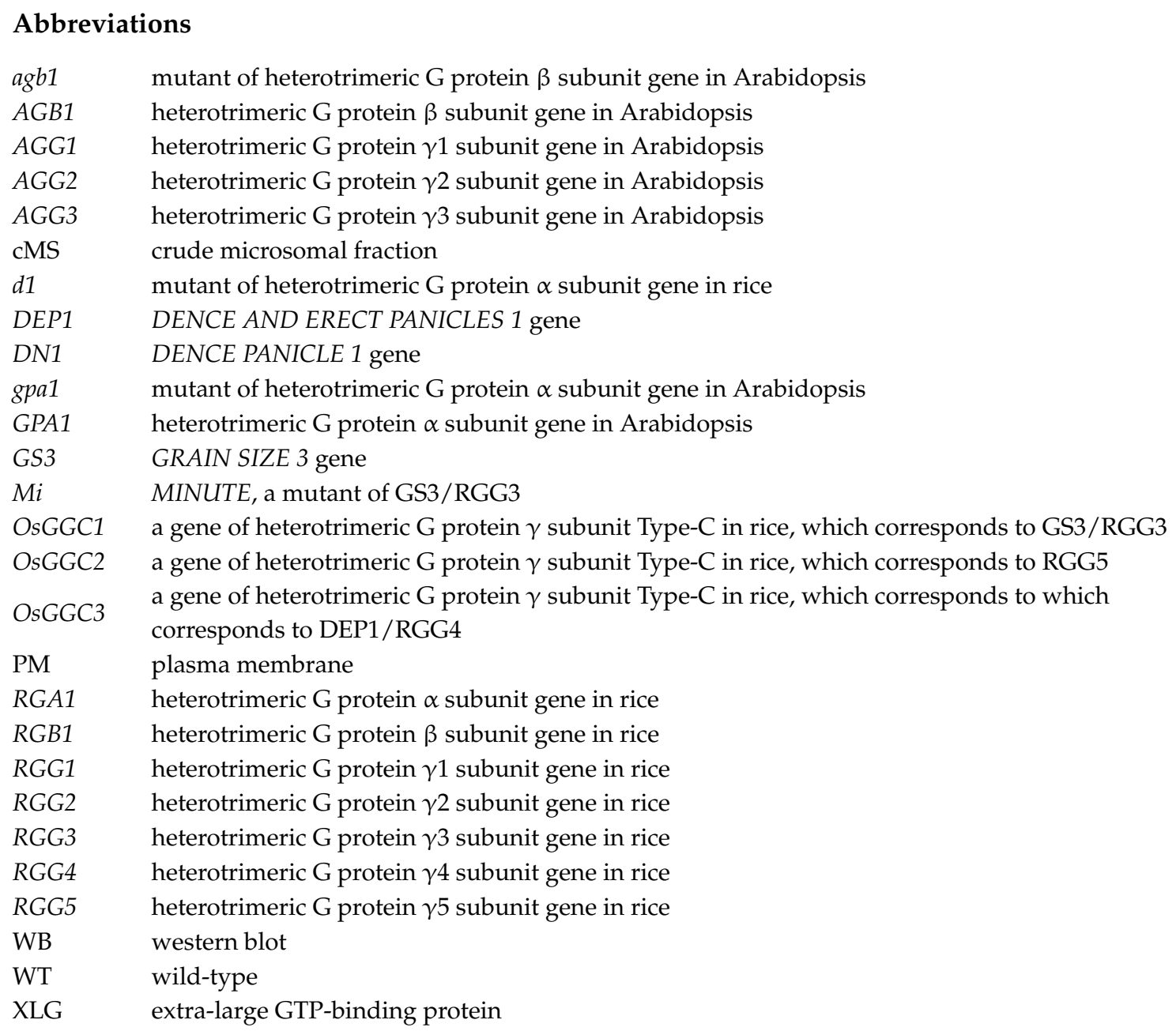

\section{References}

1. Offermanns, S. Mammalian G-protein function in vivo: New insights through altered gene expression. Rev. Physiol. Biochem. Pharmacol. 2000, 140, 63-133. [PubMed]

2. Gomperts, B.D.; Kramer, I.J.M.; Tatham, P.E.R. (Eds.) Signal Transduction; Elsevier Inc.: Amsterdam, The Netherlands, 2002.

3. Wettschureck, N.; Offermanns, S. Mammalian G proteins and their cell type specific functions. Physiol. Rev. 2005, 85, 1159-1204. [CrossRef] [PubMed]

4. Milligan, G.; Kostenis, E. Heterotrimeric G-proteins: A short history. Br. J. Pharmacol. 2006, 147, S46-S55. [CrossRef] [PubMed]

5. Temple, B.R.S.; Jones, A.M. The Plant Heterotrimeric G-Protein Complex. Annu. Rev. Plant Biol. 2007, 58, 249-266. [CrossRef] [PubMed]

6. Urano, D.; Chen, J.-G.; Botella, J.R.; Jones, A.M. Heterotrimeric G protein signalling in the plant kingdom. Open Biol. 2013, 3, 120-186. [CrossRef] [PubMed]

7. Urano, D.; Miura, K.; Wu, Q.; Iwasaki, Y.; Jackson, D.; Jones, A.M. Plant morphology of heterotrimeric G protein mutants. Plant Cell Physiol. 2016, 57, 437-445. [CrossRef] [PubMed]

8. Lee, Y.-R.J.; Assmann, S.M. Arabidopsis thaliana 'extra-large GTP-binding protein' (AtXLG1): A new class of G-protein. Plant Mol. Biol. 1999, 40, 55-64. [CrossRef] [PubMed]

9. Assmann, S.M. Heterotrimeric and unconventional GTP binding proteins in plant cell signaling. Plant Cell 2002, 355S-S373. [CrossRef]

10. Ma, H.; Yanofsky, M.F.; Meyerowitz, E.M. Molecular cloning and characterization of GPA1, a G protein $\alpha$ subunit gene from Arabidopsis thaliana. Proc. Natl. Acad. Sci. USA 1990, 87, 3821-3825. [CrossRef] [PubMed] 
11. Weiss, C.A.; Garnaat, C.W.; Mukai, K.; Hu, Y.; Ma, H. Isolation of cDNAs encoding guanine nucleotide-binding protein $\beta$-subunit homologues from maize (ZGB1) and Arabidopsis (AGB1). Proc. Natl. Acad. Sci. USA 1994, 91, 9554-9558. [CrossRef] [PubMed]

12. Mason, M.G.; Botella, J.R. Completing the heterotrimer: Isolation and characterization of an Arabidopsis thaliana G protein $\gamma$-subunit cDNA. Proc. Natl. Acad. Sci. USA 2000, 97, 14784-14788. [CrossRef] [PubMed]

13. Mason, M.G.; Botella, J.R. Isolation of a novel G-protein $\gamma$-subunit from Arabidopsis thaliana and its interaction with G $\beta$. Biochim. Biophys. Acta 2001, 1520, 147-153. [CrossRef]

14. Chakravorty, D.; Trusov, Y.; Zhang, W.; Acharya, B.R.; Sheahan, M.B.; McCurdy, D.W.; Assmann, S.M.; Botella, J.R. An atypical heterotrimeric G-protein $\gamma$-subunit is involved in guard cell $\mathrm{K}^{+}$-channel regulation and morphological development in Arabidopsis thaliana. Plant J. 2011, 67, 840-851. [CrossRef] [PubMed]

15. Wu, Q.; Regan, M.; Furukawa, H.; Jackson, D. Role of heterotrimeric G $\alpha$ proteins in maize development and enhancement of agronomic traits. PLOS Genet. 2018, 14, e1007374. [CrossRef] [PubMed]

16. Ishikawa, A.; Tsubouchi, H.; Iwasaki, Y.; Asahi, T. Molecular cloning and characterization of a cDNA for the $\alpha$ subunit of a G protein from rice. Plant Cell Physiol. 1995, 36, 353-359. [CrossRef] [PubMed]

17. Ishikawa, A.; Iwasaki, Y.; Asahi, T. Molecular cloning and characterization of a cDNA for the $\beta$ subunit of a G protein from rice. Plant Cell Physiol. 1996, 37, 223-228. [CrossRef] [PubMed]

18. Kato, C.; Mizutani, T.; Tamaki, H.; Kumagai, H.; Kamiya, T.; Hirobe, A.; Fujisawa, Y.; Kato, H.; Iwasaki, Y. Characterization of heterotrimeric $\mathrm{G}$ protein complexes in rice plasma membrane. Plant J. 2004, 38, 320-331. [CrossRef] [PubMed]

19. Fan, C.; Xing, Y.; Mao, H.; Lu, T.; Han, B.; Xu, C.; Li, X.; Zhang, Q. GS3, a major QTL for grain length and weight and minor QTL for grain width and thickness in rice, encodes a putative transmembrane protein. Theor. Appl. Genet. 2006, 112, 1164-1171. [CrossRef] [PubMed]

20. Huang, X.; Qian, Q.; Liu, Z.; Sun, H.; He, S.; Luo, D.; Xia, G.; Chu, C.; Li, J.; Fu, X. Natural variation at the DEP1 locus enhances grain yield in rice. Nat. Genet. 2009, 41, 494-497. [CrossRef] [PubMed]

21. Botella, J.R. Can heterotrimeric G proteins help to feed the world? Trend Plant Sci. 2012, 17, 563-568. [CrossRef] [PubMed]

22. Trusov, Y.; Chakravorty, D.; Botella, J.R. Diversity of heterotrimeric G-protein $\gamma$ subunits in plants. BMC Res. Notes 2012, 5, 608. [CrossRef] [PubMed]

23. Ding, L.; Pandey, S.; Assmann, S.M. Arabidopsis extra-large G proteins (XLGs) regulate root morphogenesis. Plant J. 2008, 53, 248-263. [CrossRef] [PubMed]

24. Ullah, H.; Chen, J.-G.; Young, J.C.; Im, K.-H.; Sussman, M.R.; Jones, A.M. Modulation of cell proliferation by heterotrimeric G protein in Arabidopsis. Science 2001, 292, 2066-2069. [CrossRef]

25. Lease, K.A.; Wen, J.; Li, J.; Doke, J.T.; Liscum, E.; Walker, J.C. A mutant Arabidopsis heterotrimeric G-protein $\beta$ subunit affects leaf, flower, and fruit development. Plant Cell 2001, 13, 2631-2641. [CrossRef] [PubMed]

26. Ullah, H.; Chen, J.-G.; Temple, B.; Boyes, D.C.; Alonso, J.M.; Davis, K.R.; Ecker, J.R.; Jones, A.M. The $\beta$-subunit of Arabidopsis $\mathrm{G}$ protein negatively regulates auxin-induced cell division and affects multiple developmental processes. Plant Cell 2003, 15, 393-409. [CrossRef] [PubMed]

27. Trusov, Y.; Rookes, J.E.; Tilbrook, K.; Chakravorty, D.; Mason, M.G.; Anderson, D.; Chen, J.-G.; Jones, A.M.; Botella, J.R. Heterotrimeric $G$ protein $\gamma$ subunits provide functional selectivity in $G \beta \gamma$ dimer signaling in Arabidopsis. Plant Cell 2007, 19, 1235-1250. [CrossRef] [PubMed]

28. Fujisawa, Y.; Kato, T.; Ohki, S.; Ishikawa, A.; Kitano, H.; Sasaki, T.; Asahi, T.; Iwasaki, Y. Suppression of the heterotrimeric G protein causes abnormal morphology, including dwarfism, in rice. Proc. Natl. Acad. Sci. USA 1999, 96, 7575-7580. [CrossRef] [PubMed]

29. Ashikari, M.; Wu, J.; Yano, M.; Sasaki, T.; Yoshimura, A. Rice gibberellin-insensitive dwarf mutant gene Dwarf 1 encodes the $\alpha$-subunit of GTP-binding protein. Proc. Natl. Acad. Sci. USA 1999, 96, 10284-10289. [CrossRef] [PubMed]

30. Mao, H.; Sun, S.; Yao, J.; Wang, C.; Yu, S.; Xu, C.; Li, X.; Zhang, Q. Linking differential domain functions of the GS3 protein to natural variation of grain size in rice. Proc. Natl. Acad. Sci. USA 2010, 107, 19579-19584. [CrossRef] [PubMed]

31. Izawa, Y.; Takayanagi, Y.; Inaba, N.; Abe, Y.; Minami, M.; Fujisawa, Y.; Kato, H.; Ohki, S.; Kitano, H.; Iwasaki, Y. Function and expression pattern of the $\alpha$ subunit of the heterotrimeric G protein in rice. Plant Cell Physiol. 2010, 51, 271-281. [CrossRef] [PubMed] 
32. Utsunimiya, U.; Samejima, C.; Takayanagi, Y.; Izawa, Y.; Yoshida, T.; Sawada, Y.; Fijisawa, Y.; Kato, H.; Iwasaki, Y. Suppression of the rice heterotrimeric $G$ protein $\beta$-subunit gene, RGB1, causes dwarfism and browning of internodes and lamina joint regions. Plant J. 2011, 67, 907-916. [CrossRef] [PubMed]

33. Wang, X.Q.; Ullah, H.; Jones, A.M.; Assmann, S.M. G protein regulation of ion channels and abscisic acid signaling in Arabidopsis guard cells. Science 2001, 292, 2070-2072. [CrossRef] [PubMed]

34. Coursol, S.; Fan, L.M.; Le Stunff, H.; Spiegel, S.; Gilroy, S.; Assmann, S.M. Sphingolipid signalling in Arabidopsis guard cells involves heterotrimeric G proteins. Nature 2003, 423, 651-654. [CrossRef] [PubMed]

35. Lapik, Y.R.; Kaufman, L.S. The Arabidopsis cupin domain protein AtPirin1 interacts with the G protein $\alpha$-Subunit GPA1 and regulates seed germination and early seedling development. Plant Cell 2003, 15, 1578-1590. [CrossRef] [PubMed]

36. Pandey, S.; Assmann, S.M. The Arabidopsis putative G protein-coupled receptor GCR1 interacts with the G protein $\alpha$ subunit GPA1 and regulates abscisic acid signaling. Plant Cell 2004, 16, 1616-1632. [CrossRef] [PubMed]

37. Mishra, G.; Zhang, W.; Deng, F.; Zhao, J.; Wang, X. A bifurcating pathway directs abscisic acid effects on stomatal closure and opening in Arabidopsis. Science 2006, 312, 264-266. [CrossRef] [PubMed]

38. Ueguchi-Tanaka, M.; Fujisawa, Y.; Kobayashi, M.; Ashikari, M.; Iwasaki, Y.; Kitano, H.; Matsuoka, M. Rice dwarf mutant $d 1$, which is defective in the $\alpha$ subunit of the heterotrimeric $G$ protein, affects gibberellin signal transduction. Proc. Natl. Acad. Sci. USA 2000, 97, 11638-11643. [CrossRef] [PubMed]

39. Ullah, H.; Chen, J.G.; Wang, S.; Jones, A.M. Role of a heterotrimeric G protein in regulation of Arabidopsis seed germination. Plant Physiol. 2002, 129, 897-907. [CrossRef] [PubMed]

40. Chen, J.G.; Pandey, S.; Huang, J.; Alonso, J.M.; Ecker, J.R.; Assmann, S.M.; Jones, A.M. GCR1 can act independently of heterotrimeric G-protein in response to brassinosteroids and gibberellins in Arabidopsis seed germination. Plant Physiol. 2004, 135, 907-915. [CrossRef] [PubMed]

41. Bethke, P.C.; Hwang, Y.S.; Zhu, T.; Jones, R.L. Global patterns of gene expression in the aleurone of wild-type and dwarf1 mutant rice. Plant Physiol. 2006, 140, 484-498. [CrossRef] [PubMed]

42. Chen, J.-G.; Jones, A.M. AtRGS1 function in Arabidopsis thaliana. Method. Enzymol. 2004, 389, $338-350$. [CrossRef]

43. Huang, J.; Taylor, J.P.; Chen, J.G.; Uhrig, J.F.; Schnell, D.J.; Nakagawa, T.; Korth, K.L.; Jones, A.M. The plastid protein THYLAKOID FORMATION1 and the plasma membrane G-protein GPA1 interact in a novel sugar-signaling mechanism in Arabidopsis. Plant Cell 2006, 18, 1226-1238. [CrossRef] [PubMed]

44. Warpeha, K.M.; Hamm, H.E.; Rasenick, M.M.; Kaufman, L.S. A blue-light-activated GTP-binding protein in the plasma membranes of etiolated peas. Proc. Natl. Acad. Sci. USA 1991, 88, 8925-8929. [CrossRef] [PubMed]

45. Warpeha, K.M.; Lateef, S.S.; Lapik, Y.; Anderson, M.; Lee, B.S.; Kaufman, L.S. G-protein-coupled receptor 1, G-protein $\mathrm{G} \alpha$-subunit 1, and Prephenate dehydratase 1 are required for blue light-induced production of phenylalanine in etiolated Arabidopsis. Plant Physiol. 2006, 140, 844-855. [CrossRef] [PubMed]

46. Joo, J.H.; Wang, S.; Chen, J.G.; Jones, A.M.; Fedoroff, N.V. Different signaling and cell death roles of heterotrimeric $G$ protein $\alpha$ and $\beta$ subunits in the Arabidopsis oxidative stress response to ozone. Plant Cell 2005, 17, 957-970. [CrossRef] [PubMed]

47. Suharsono, U.; Fujisawa, Y.; Kawasaki, T.; Iwasaki, Y.; Satoh, H.; Shimamoto, K. The heterotrimeric G protein $\alpha$ subunit acts upstream of the small GTPase Rac in disease resistance of rice. Proc. Natl. Acad. Sci. USA 2002, 99, 13307-13312. [CrossRef] [PubMed]

48. Komatsu, S.; Yang, G.; Hayashi, N.; Kaku, H.; Umemura, K.; Iwasaki, Y. Alterations by a defect in a rice G protein $\alpha$ subunit in probenazole and pathogen-induced responses. Plant Cell Environ. 2004, 27, 947-957. [CrossRef]

49. Iwata, M.; Umemura, K.; Teraoka, T.; Usami, H.; Fujisawa, Y.; Iwasaki, Y. Role of the $\alpha$ subunit of heterotrimeric G-protein in probenazole-inducing defense signaling in rice. J. Gen. Plant Pathol. 2003, 69, 83-86. [CrossRef]

50. Lieberherr, D.; Thao, N.P.; Nakashima, A.; Umemura, K.; Kawasaki, T.; Shimamoto, K. A sphingolipid licitor-inducible mitogen-activated protein kinase is regulated by the small GTPase OsRac1 and heterotrimeric G-protein in rice. Plant Physiol. 2005, 138, 1644-1652. [CrossRef] [PubMed]

51. Wang, S.; Assmann, S.M.; Fedoroff, N.V. Characterization of the Arabidopsis heterotrimeric G protein. J. Biol. Chem. 2008, 283, 13913-13922. [CrossRef] [PubMed] 
52. Klopffleish, K.; Phan, N.; Augstin, K.; Bayne, R.; Booker, K.S.; Bolella, J.; Carpita, N.C.; Carr, T.; Chen, J.-C.; Cooke, T.R.; et al. Arabidopsis G-protein interactome reveals connections to cell wall carbohydrates and morphogenesis. Mol. Syst. Biol. 2011, 7, 532. [CrossRef] [PubMed]

53. Chen, J.-G.; Willard, F.S.; Huang, J.; Liang, J.; Chasse, S.A.; Jones, A.M.; Siderovski, D.P. A seven-transmembrane RGS protein that modulates plant cell proliferation. Science 2003, 301, 1728-1731. [CrossRef] [PubMed]

54. Adjobo-Hermans, M.J.; Goedhart, J.; Gadella, T.W., Jr. Plant G protein heterotrimers require dual lipidation motifs of $G \alpha$ and $G \gamma$ and do not dissociate upon activation. J. Cell Sci. 2006, 119, 5087-5097. [CrossRef] [PubMed]

55. Sun, H.; Qian, Q.; Wu, K.; Lou, J.; Wang, S.; Zhang, C.; Ma, Y.; Lie, Q.; Huang, X.; Yuan, Q.; et al. Heterotrimeric $G$ proteins regulate nitrogen-use efficiency in rice. Nat. Genet. 2014, 46, 652-656. [CrossRef] [PubMed]

56. Sun, S.; Wang, L.; Mao, H.; Shao, L.; Li, X.; Xiao, J.; Ouyang, Y.; Zhang, Q. A G-protein pathway determines grain size in rice. Nat. Commun. 2018, 9, 815-824. [CrossRef]

57. Takano-Kai, N.; Jiang, H.; Kubo, T.; Sweeney, M.; Matsumoto, T.; Kanamori, H.; Padhukasahasram, B.; Bustamante, C.; Yoshimura, A.; Doi, K.; et al. Evolutionary history of GS3, a gene conferring grain length in rice. Genetics 2009, 182, 1-12. [CrossRef] [PubMed]

58. Takano-Kai, N.; Jiang, H.; Powell, A.; McCouch, S.; Takamure, I.; Furuya, N.; Doi, K.; Yoshimura, A. Multiple and independent origins of short seeded alleles of GS3 in rice. Breed. Sci. 2013, 63, 77-85. [CrossRef] [PubMed]

59. Sambrook, J.; Russell, D.W. (Eds.) Molecular Cloning; Cold Spring Harbor Laboratory Press: Cold Spring Harbor, NY, USA, 2001.

60. Yoshida, S.; Uemura, M.; Niki, T.; Sakai, A.; Gusta, L.V. Partition of membrane particles in aqueous two-polymer phase system and its partial use for purification of plasma membranes from plants. Plant Physiol. 1983, 72, 105-114. [CrossRef] [PubMed]

61. Iwasaki, Y.; Kato, T.; Kaidoh, T.; Ishikawa, A.; Asahi, T. Characterization of the putative $\alpha$ subunit of a heterotrimeric G protein in rice. Plant Mol. Biol. 1997, 34, 563-572. [CrossRef] [PubMed] 